$\S=-1$

\title{
Variation of Beach Profile Along Pahang Coast in Malaysia
}

\author{
Fazly Amri Mohd ${ }^{1}$, Khairul Nizam Abdul Maulud, ${ }^{1,2}$, Rawshan Ara Begum ${ }^{3}$, Othman A. Karim ${ }^{1}$, Md Firoz Khan $^{4}$, \\ Siti Norsakinah Selamat ${ }^{2}$, Abdul Aziz Ab Rahman ${ }^{2}$, Mohd Aizat Saiful Bahri ${ }^{2}$, Sharifah Mastura Syed Abdullah ${ }^{2}$, \\ Mohd Khairul Amri Kamarudin ${ }^{5}$, Muhammad Barzani Gasim ${ }^{5}$, Hafizan Juahir ${ }^{5}$ \\ ${ }^{I}$ Department of Civil and Structural Engineering, Faculty of Engineering and Built Environment,Universiti Kebangsaan Malaysia, \\ 43600 UKM Bangi, Selangor, Malaysia \\ ${ }^{2}$ Earth Observation Centre, Institute of Climate Change (IPI),Universiti Kebangsaan Malaysia, 43600 UKM Bangi, Selangor, Malaysia \\ ${ }^{3}$ Center for Water Cycle, Marine Environment and Disaster Management (CWMD), Kumamoto University, 2-39-1 Kurokami, Chuo-ku, \\ Kumamoto 860-8555, Japan \\ ${ }^{4}$ Centre for Tropical Climate Change System, Institute of Climate Change, Universiti Kebangsaan Malaysia, 43600 Bangi, Selangor, \\ Malaysia \\ ${ }^{5}$ East Coast Environmental Research Institute (ESERI), Universiti Sultan Zainal Abidin (UniSZA), Gong Badak Campus, 21300 Kuala \\ Nerus, Terengganu, Malaysia \\ *Corresponding author E-mail: knam@ukm.edu.my
}

\begin{abstract}
Pahang is placed at the east coast of Peninsular Malaysia and has a lot of attractive coasts with interesting scenery, which can capture the attention of people to the coasts. The seven (7) of significant coasts namely Pantai Cherating, Holiday Villa beach, Pantai Balok, Sungai Ular, Pantai Sepat, Pantai Cheruk Palok and Pantai Tanjung Agas are classified has experienced about erosion coastal problem especially having significantly for social, environment and economic value recreational activities along of this shoreline. Coastal erosion is recognized as the permanent loss of land and habitats along of the coast. The variation of beach profile characteristics along the shoreline of Pahang will be identified and described using the beach profile survey and interpolation technique. From that, the information of erosion and accretion for topography surface of coastal was generated by calculating distance and elevation of coasts. Most of these study are consist the sandy coastal. Hence the ranges value of coastal width for Tanjung Agas is shows high value of erosion and accretion with 7.74 and $3.93 \mathrm{~m} /$ year. To sum up, the findings of study might be useful in significant decision making for protecting and mitigation measures towards sustainable coastal management along the Pahang coastal.
\end{abstract}

Keywords: Beach profile survey; Pahang coast; Erosion; Sustainable; Accretion.

\section{Introduction}

The coastal area can be defined as the interface between land and sea. This area is mostly high vulnerable to natural hazards of the climate changes especially during storms and sea level rise problem [1-2]. In [3-4] also has mentioned that factors of wave and tidal forces, wind, sediment, and initial topography would be influenced the natural coasts. This is supported by [5] study which reveal that most of $70 \%$ of the world's coasts are facing serious hazard problem especially coastal erosion to many coastal regions. These regions are naturally dynamic and often exposed to natural factors such as river flows, waves and storms as well as human interferences that frequently reform the coastal of geomorphology [6]. The processes of geomorphic and oceanographic at the coast area is always changes that taking over different of time and spatial scales. In fact, coastal areas also impacted to the economic performance as well as other aspects of human health [7-9]. The coastal zones are important assets for the physical resources, wildlife, protection against flooding and recreation in the most of the countries in the world. The shoreline position may confront changes from year to year due to two major factors which are natural phenomena and human activities. In addition, unplanned development at coastal area is a major factor of shoreline changes due to the human activities. One study by [10-11] mentioned that the coastal area was classified as a most difficult to manage due to its density and to the huge concentration of human activities along of the shoreline. Furthermore, these area are considered to be a fragile area because it is easily affected to their surrounding activities

Nowadays, in [12] claimed that the coastal areas are facing the natural and anthropogenic interference consists of sea level rise event, coastal erosion problem and others. Sea level rise for instance, has the potential to affect coastal environments in several ways including increased flooding, increased erosion, and changes in tidal flows and elevations [13]. Moreover, these findings are supported by the findings [14] which showed that changes in tidal hydrodynamics under sea level rise may impact to navigation, ecological habitats, infrastructure, and the geomorphology of the shoreline. Furthermore, hydrodynamics of tidal definitely also will influence inundation, circulation and sediment transport processes. In order to determine the beach profile changes, there are many survey methods can be employed, whether it is short or long term period. In [15] revealed that the beach profile of changes are commonly required collection of data series of the topography profile surveys over a weekly basis. These findings are supported by the findings of [16] which showed that this technique is very 
simple and economic, and demonstrated the capability to monitor geomorphology of coastal evolution.

A novel study by [14] revealed that the surveying techniques for determined the beach profile using total station (EDM) also represented in very high accuracy result. Nevertheless, study by [16] found the opposite to be true. Although their study showed this technique have several problem such as errors that are additive and can be mostly large on wide beaches and obstruction of view by objects during measurement.

The understanding and properties of coastal dynamics are most vital both for scientific information and for a sustainable management of the coast. However, surprisingly, no extensively studied has been made and less much information related about the geomorphology of Pahang Coast. Therefore, the aim of this study attempts to identify and describe the variation of beach profile characteristics along the shoreline of Cherating to Pekan.

\section{Material and Methods}

\subsection{Study Area}

The study area comprises of seven distinguish beach profile in Pahang, from Pantai Cherating ( $\left.4^{\circ} 7^{\prime} 29.83^{\prime \prime} \mathrm{N}, 103^{\circ} 23^{\prime} 47.59^{\prime \prime} \mathrm{E}\right)$ located at the north eastern of the state to Tanjung Agas $\left(3^{\circ} 30^{\prime} 32.02^{\prime \prime} \mathrm{N}, 103^{\circ} 28^{\prime} 34.57^{\prime \prime} \mathrm{E}\right)$ where it is located at the southern east of the state as shown Figure 1. Located in the eastern region, the coastline of study area is facing the South China Sea where the coastline consists of sandy and muddy beaches with a total length of $209 \mathrm{~km}$ [17].

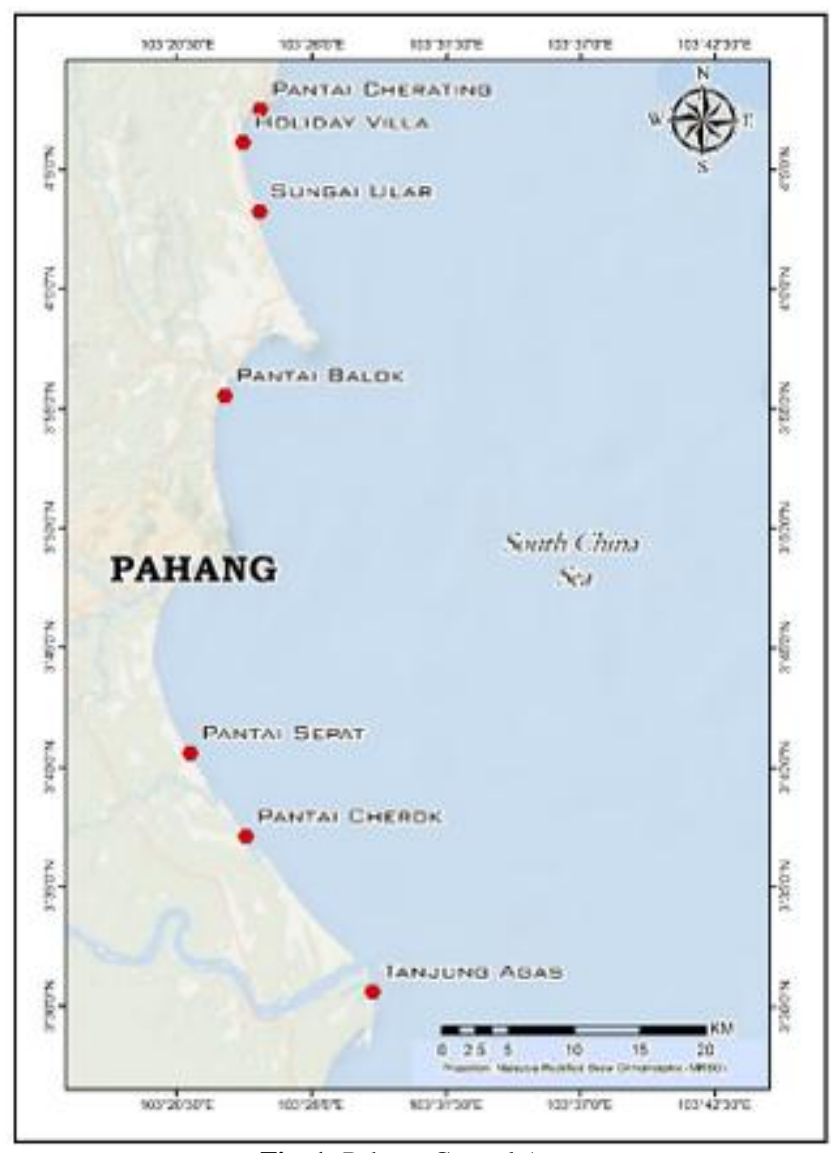

Fig. 1: Pahang Coastal Area

Based on the NCES 1985, these area were classified as a high erosion of coastal among of East Coast of Peninsular Malaysia with known as $\mathrm{K} 1$ and $\mathrm{K} 2$ category. Furthermore, approximately $46.3 \%$ of Pahang's shorelines have undergone erosion which accounts for $125.4 \mathrm{~km}$ of its length [18]. The coastline is nearly fully exposed and vulnerable to the attack of wave from the South China Sea. The climate condition in the areas are monsoon season's type, where it is known as the southwest monsoon (From May to September), Northeast monsoon (from November to March) and two shorter periods of inter-monsoon seasons which consist of annual rainfall between 1488 to $3071 \mathrm{~mm}$ [19].

The data obtained consist of $\mathrm{x}, \mathrm{y}$ and $\mathrm{z}$ axis using survey method. This observation has been done throughout the total station survey. All the data was imported and processed in ESRI ArcGIS 10.4 software. The data then was imported to KML in order to visually verify in Google Earth to get more accurate location. All incomplete data.

\subsection{Data Collection and Source}

The beach topographic or profile survey was carried out using survey method which consist of total station survey for distance and elevation in each beach namely Tanjung Agas, Sungai Ular, Pantai Sepat, Pantai Cherok, Pantai Cherating, Pantai Balok and Pantai Holiday Villa. These beach vulnerabilities were determined based on previous study where it is crucial to monitor the changes on the selection beaches.

The survey was conducted in August 2016. The topographic data was collected on low tide condition which based on tide table obtain from Pusat Hidrografi Nasional in order to cover the range of data collection as far to the water edge [4]. The average length of the longshore coverage for every beach is approximately $200 \mathrm{~m}$ with a $50 \mathrm{~m}$ interval between transect line. The interval was set at regular interval unless there are changes in the elevation. Point coverage and interval are varied between site depending on field conditions, weather, equipment and availability of personnel.

\subsection{Spatial Interpolation Technique}

Spatial interpolation technique is the process to interpolate or estimate the unknown value for specific locations based on the known data values for other points. Interpolation technique or methods can be divided into two main group which are global and local. As the name indicate, the global interpolation technique use all available data to provide estimates for the points with unknown values, while local interpolation techniques use only the information in the vicinity of the point estimated [14].

\subsection{Inverse Distance Weighting (IDW)}

In order to map the profile and surface of the coastline, Inverse Distance Weighting spatial interpolation technique was used where it is based on the assumption that the nearby values contribute more to the interpolated values than distant observations. In brief, the influence of a known point is inversely related to the distance from the unknown location that is being estimated [20]. Using the so-called "Inverse Distance Weighting" method or IDW the weight of any known point is set inversely proportional to its distance from the estimated point. It is calculated as in Equation (1):

$\hat{V}=\frac{n \sum_{i=1}^{n} \frac{1}{d i} v i}{\sum_{i=1}^{m} \frac{1}{d i}}$

where $\widehat{V}$ is the value to be estimated, $v i$ is the known value while $d i$ is the distances from the $n$ data points to the point estimated $n, d i=\sqrt{(x-x i)^{2}+(y-y i)^{2}} .(x, y)$ are the coordinates of the interpolation point and (xi,yi) are the coordinates of each dispersion point. The weight function varies with a value of unity at the dispersion point to a value close to zero as the distance to the dispersion point increase. 
The IDW interpolation technique indicates the degree of increment and decrement pattern for certain transect line for each beach. In other words, the value of the increment and decrement consist of some extreme elevation changes for the beach profile. The IDW algorithm was applied to generate a Digital Elevation Model (DEM) that converts survey point data into continuous field grids. Figures is the result for each station established at the beach.

\section{Results and Discussion}

\subsection{Coastal Profile}

All locations site have the same trends of beach profile as shown as Table 1. Tanjung Agas, Pantai Cheruk Palok and Pantai Sepat had widest and longest beach with the interval chainage by horizontal direction between two stations are $300 \mathrm{~m}$. Meanwhile, Pantai Sungai Ular, Pantai Cherating, Pantai Balok and Pantai Legend Villa are classified as shortest beach with the interval for each of chainage are almost $250 \mathrm{~m}$. Using the interpolation technique, the green colour is represented as the coastal land, while blue colour is refer to water body area of location. The range value of the coastal land of these location are indicated between $2.0-7.5 \mathrm{~m}$ above of mean sea level (MSL).

\subsection{Geomorphology of coastal}

The distribution of profile stations along the seven area facing the South China Sea. The findings of in-situ measurement are show that these location of Pahang coastal consists of sand beach. Previous studies was conducted by [21] revealed that the shoreline of the Cherating have rocky shores and sandy beaches except at the mouth of the river where the sand spit are formed. According to recent studies by [17] also proved the study's findings that $\mathrm{Pa}$ hang's beaches have rocky shores located in Teluk Cempedak and Tanjung Tembeling, the muddy coastline of Tanjung Lumpur and the sandy shores are located in Kuala Pahang. These findings are supported by the findings of $[22,18]$ which showed that coastal of Sungai Ular, Balok and Tanjung Agas are consists fine sand and medium sand respectively.

Based on Table 2, it shows that the profile section topographic of Pahang coast. From seven area of study area, Pantai Cherating, Legend Villa and Tanjung Agas has steeper slope with ranges value between $1.5-3.6 \%$ respectively. Meanwhile, coastal of Sungai Ular, Pantai Balok, Pantai Sepat and Cheruk Paloh are shows that these location so flatten and wider areas. According to [18] reveals that coastal of Cherating, Teluk Chempedak, Tanjung Lumpur and Pantai Sepat are the examples of the most fascinating beaches in Pahang, which attract people for recreational activities. These coastal as known as beautiful beaches with captivating scenery and background, which can attract the attention of visitors to the beaches.

Table 1: The Beach Profile of study area

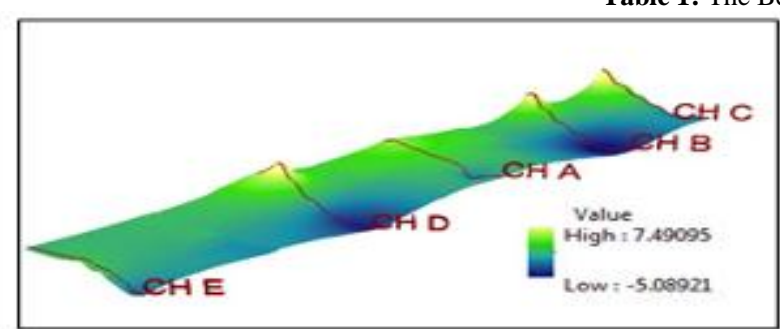

Rantai Taniuns Agas

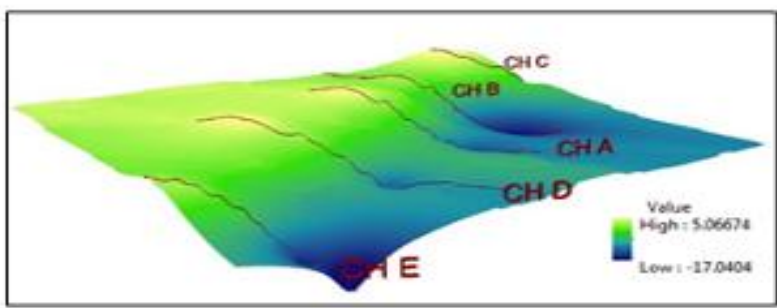

Pantai Sepat

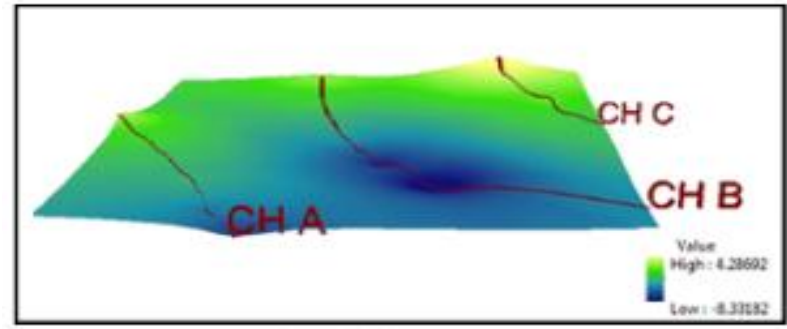

Rantai Cherating

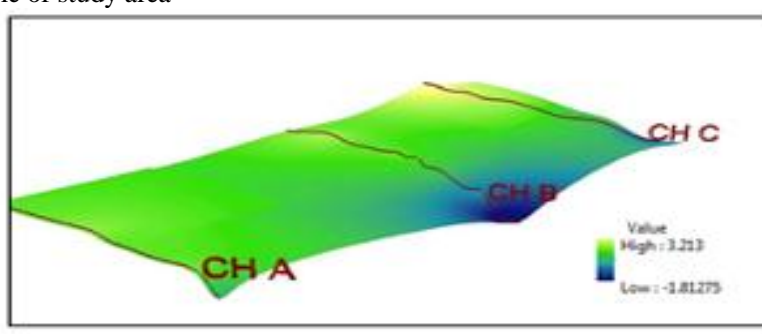

Pantai Sungai Ular

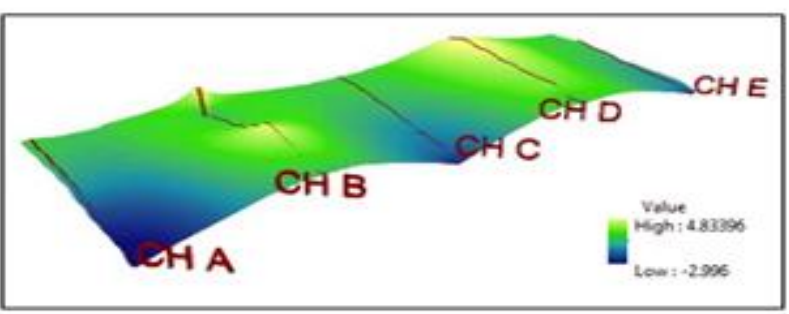

Pantai Chenuk Paloh

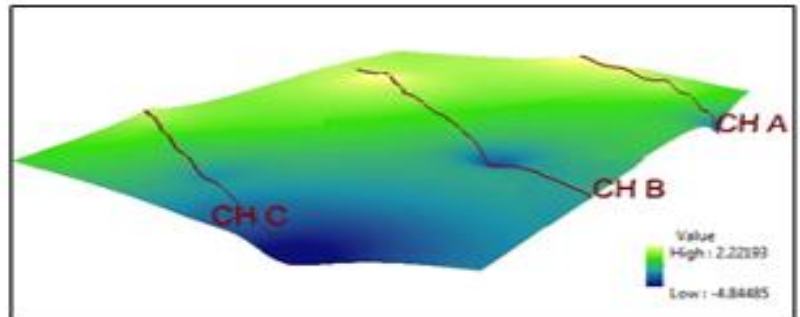

Pantai Balek

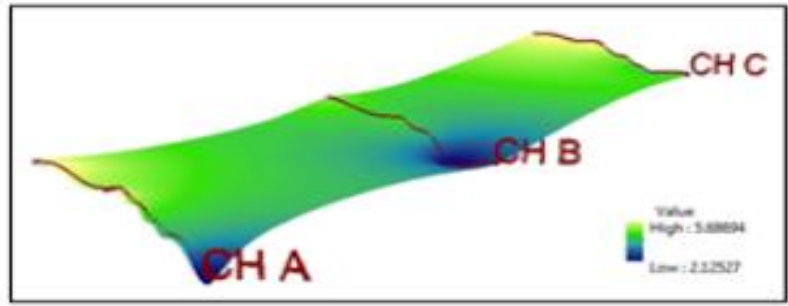

Pantai Legend Villa 
Table 2: Cross section of Beach Profile at Study Area

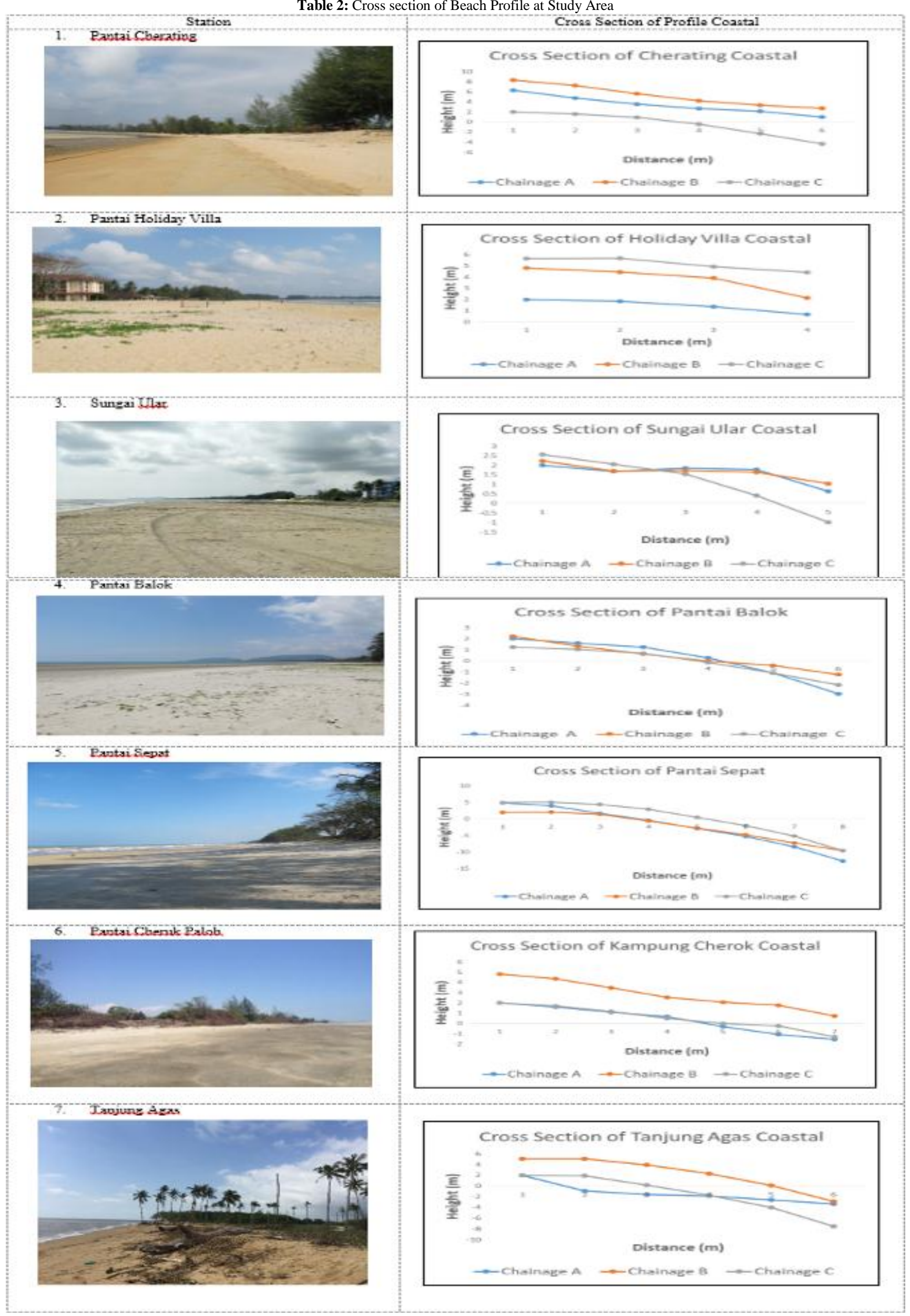




\subsection{The Rate of Erosion and Accretion of Coastal}

Coastal erosion was caused by currents, wave action and tidal that shall make a long term losses of sediments an impacted the physical of coastal. Coastal erosion occurs when the shore loses their sediments which resulting in reduction of sediment budget. Therefore, theses shoreline change their shape and size from time to time as a response to waves, currents and tides. Based on the Figure 2, Cherating, Holiday Villa and Tanjung Agas are shows high value of erosion with rate of erosion between -0.95 to -7.74 $\mathrm{m} /$ year. Comparing beach profile in this study, no significant changes of accretion were found in two stations which are Cherating and Balok coastal, meanwhile the higher of accretion value show at Tanjung Agas with $3.93 \mathrm{~m} /$ year among of study area. Regarding studies from [18, 22-23] reveals that erosion or accretion could occur on the backshore and the sand ridges caused by waves during the northeast monsoon with higher level on the beach and further inland. Based on the location of shoreline that facing the South China Sea, this result also supported by [24] with mentioned that beach erosion occurring along the shoreline of the east coast states of Peninsular Malaysia is caused only by the large waves of the northeast monsoon seasons.

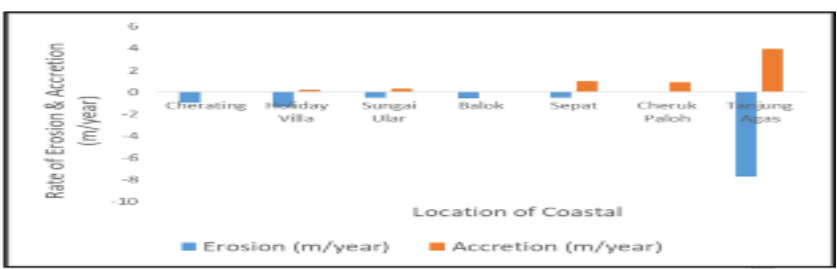

Fig. 2: The Bar Graph about rate of Erosion and Accretion (m/year)

Based on the Figure 3 and Figure 4, the findings of surface elevation and current speed along these location using MIKE21 modeling indicate the values were 1.20 to $1.35 \mathrm{~m}$ above and $0.15-0.45$ $\mathrm{m} / \mathrm{s}$ respectively. In [20] had mentioned the strong waves can affect and modify erosion in coastal zone areas during a monsoon storm. According to [23] added that the significant wave height during Northeast and Southwest Monsoon conditions on the east coast of Peninsular Malaysia ranges from $2 \mathrm{~m}$ and 0.5 to $1 \mathrm{~m}$ respectively.

Another reason of erosion and accretion are occur of these location caused by wind action on beaches with fine to medium sand. Most of these coastal location are sandy, the finding from [22] reveals that wide berms coastal of fine sand provide freely sources of material for drying and removal by wind through the year. As a result, the wind is strongly enough to blow sand material to inland during northeast monsoon. Research findings by [25] also point towards that the location of coastal that have a flat slope has the tendency to expose erosion while higher steeper slope of coastal that might undergo a period of accretion. Therefore, the coastal profile in this study shows that erosion and accretion events occur on low-lying area.

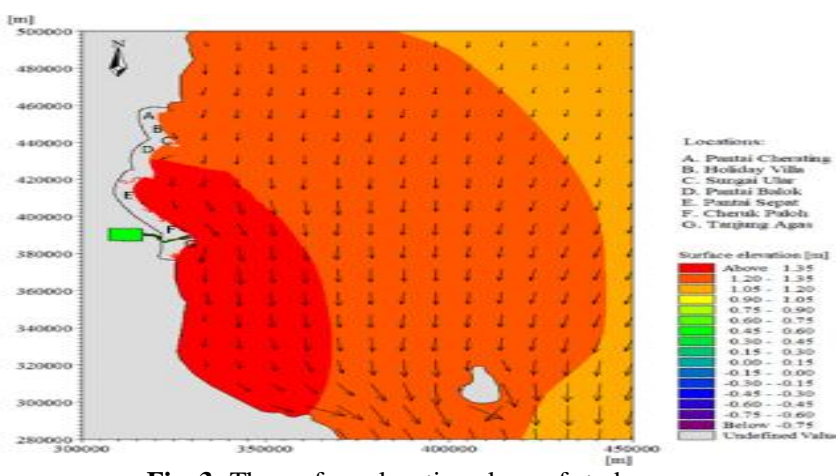

Fig. 3: The surface elevation along of study area

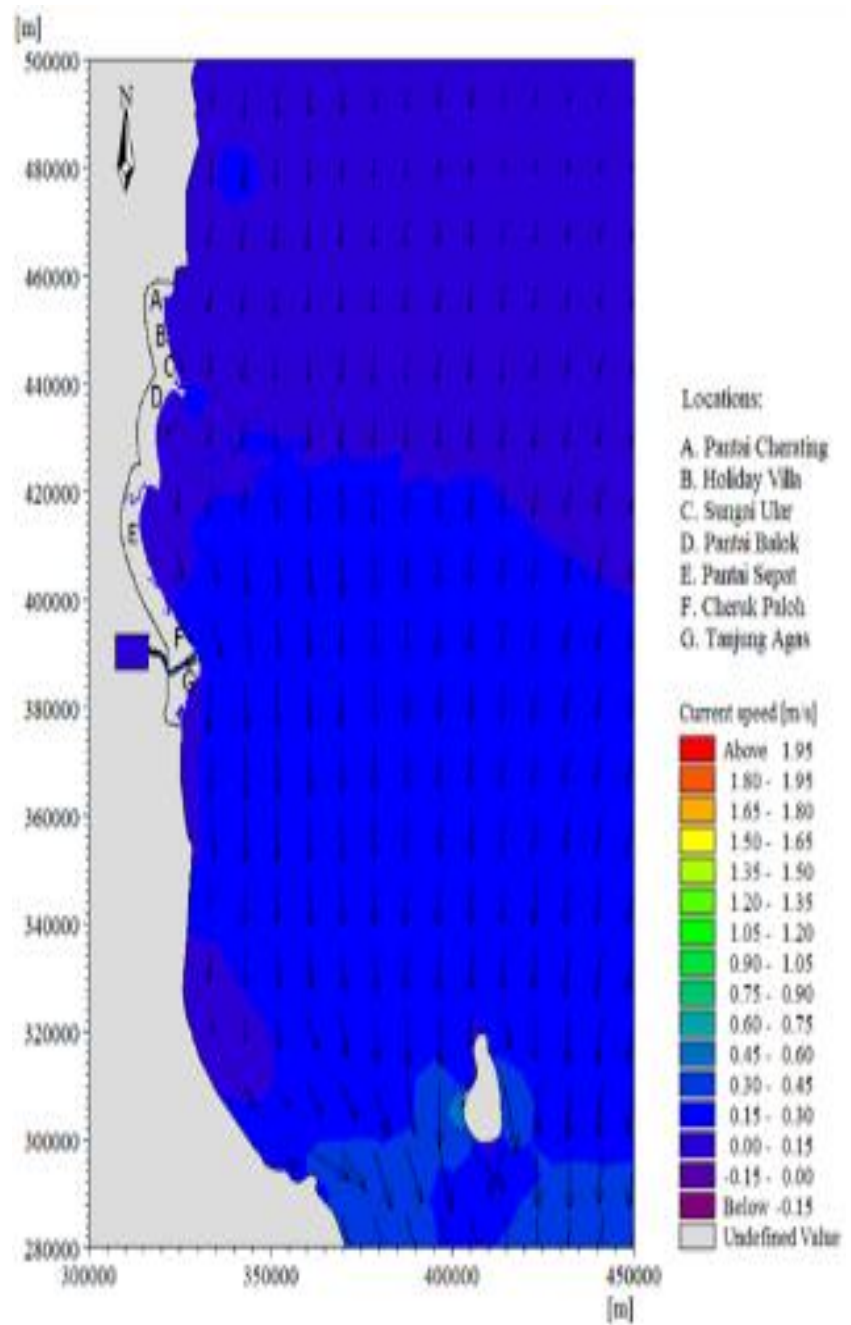

Fig. 4: The current speed $(\mathrm{m} / \mathrm{s})$ along of study area

\section{Conclusion}

Coastal areas are mostly important resources for most countries in the world for the purpose of physical resources, wildlife, and protection against flooding, safety and recreation. The changes of beach profile characteristics along the Pahang shoreline was caused by northeast monsoon and human activities. The beach profile measurement is an easy way to measure a beach crosssection, the simplest expression of beach morphology. The output of this study so far had provide additional information about the geomorphology and rate of erosion and accretion characteristics of Pahang coast. Further study can increase understanding of the hydrodynamic parameter effects towards the coastal area and coastal community. Therefore, further research might investigate useful the coastal modeling of Pahang region using the numerical modeling and existing approaches.

\section{Acknowledgement}

This study was supported by the research grants of Trans Disciplinary Research Grant Scheme (TRGS/1/2015/UKM/02/5/1) and Research University Grant (AP-2015-009). The authors gratefully acknowledge to the Earth Observation Centre, Institute of Climate Change, UKM for sharing the satellite data

\section{References}

[1] Abuodha, P. A. O., \& Woodroffe, C. D. (2010). Assessing 
vulnerability to sea-level rise using a coastal sensitivity index: A case study from southeast Australia. Journal of Coastal Conservation, 14(3), 189-205.

[2] Aznie, R., Usman, Y., Suriati, G., Mn, A. R., Mz, R., Nove, L. \& Mohd Fuad, M. 2012. The coastal beach of Besut, Terengganu as a preferred tourist destination. Malaysia Journal of Society and Space 8(4): 64-74.

[3] Yoo, C. I., \& Oh, T. S. (2016). Beach volume change using UAV photogrammetry Songjung beach, Korea. In International Archives of the Photogrammetry, Remote Sensing and Spatial Information Sciences - ISPRS Archives Vol. 41, pp:1201-1205..

[4] Khairul Nizam Abdul Maulud, Z. H. \& O. A. K. 2015. Kejituan Datum Carta dalam Tempoh Cerapan Pasang Surut: Jurnal Kejuruteraan 27: 103-109.

[5] Addo, K. A., \& Kodzo, K. S. (2013). Medium resolution satellite imagery as a tool for monitoring shoreline change. Case study of the Eastern coast of Ghana. Journal of Coastal Research, Special Is (65), 511-516.

[6] Bio, A., Bastos, L., Granja, H., Pinho, J. L. S., Gonçalves, J. A., Henriques, R., Rodrigues, D. (2015). Methods for coastal monitoring and erosion risk assessment: two Portuguese case studies. Revista de Gestão Costeira Integrada, 15(1), 47-63.

[7] Bosello, F., \& De Cian, E. (2014). Climate change, sea level rise, and coastal disasters. A review of modeling practices. Energy Economics, 46, 593-605.

[8] Delgado, I., \& Lloyd, G. (2004). A Simple Low Cost Method for One Person Beach Profiling. Journal of Coastal Research, 12461252.

[9] Noorazuan Md Hashim. 2010. Analisis tren pemanasan global dan kesannya terhadap aspek daya huni bandar di Malaysia. Geografia Malaysian Journal of Society and Space 6(2): 72-88.

[10] Raji, O., Niazi, S., Snoussi, M., Dezileau, L., \& Khouakhi, A. (2013). Vulnerability assessment of a lagoon to sea level rise and storm events: Nador lagoon (NE Morocco). Journal of Coastal Research, (spec. issue 65), 802-807.

[11] Chen, C., Zuo, J., Chen, M., Gao, Z., \& Shum, C.-K. (2014). Sea level change under IPCC-A2 scenario in Bohai, Yellow, and East China Seas. Water Science and Engineering, 7(4), 446-456.

[12] Imaduddina, A. H., \& Subagyo, W. W. H. (2014). Sea Level Rise Flood Zones: Mitigating Floods in Surabaya Coastal Area Procedia - Social and Behavioral Sciences, 135, 123-129.

[13] Cooper, J. A. G., \& Pilkey, O. H. (2004). Sea-level rise and shoreline retreat: Time to abandon the Bruun Rule. Global and Planetary Change, 43(3-4), 157-171.

[14] Huang, J., Jackson, D. W. T., \& Cooper, J. A. G. (2002) Morphological Monitoring of a High Energy Beach System Using GPS and Total Station Techniques, Runkerry, Co. Antrim, Northern Ireland. Journal of Coastal Research, 398(36), 390-398.

[15] Delgado, I., \& Lloyd, G. (2004). A Simple Low Cost Method for One Person Beach Profiling. Journal of Coastal Research, 204(2004), 1246-1252.

[16] Croft, L. C. (2014). Interpolating Beach Profile Data Using Linear and Non-linear Functions. Thesis, pp 1-58.

[17] Mustapa, M. Z., Saad, S., Hadi, M. S. A., Yunus, K., \& Sapon, N. (2015). Beach-face morphodynamics of different morphological setting along Teluk Chempedak to Kuala Pahang, Malaysia. Jurnal Teknologi, 77(25), 51-56.

[18] Azid, A., Noraini, C., Hasnam, C., Juahir, H., Amran, M. A., Toriman, M. E., Kamarudin, A. (2015). Jurnal Teknologi Full paper Coastal Erosion Measurement Along Tanjung Lumpur to Cherok Paloh, Pahang During the Northeast Monsoon Season. Journal Teknologi, 1, 27-34.

[19] Muhammad Barzani Gasim, Mohd. Ekhwan Toriman, Sahibin Abd Rahim, Mir Sujaul Islam, T. C. C. \& H. J. (2006). Hydrology and Water Quality and Land-use Assessment of Tasik Chini Feeder Rivers, Pahang Malaysia. Geografia, (3), 1-16.

[20] Chempalayil, S. P., Kumar, V. S., Dora, G. U., \& Johnson, G. (2014). Near shore waves, long-shore currents and sediment transport along micro-tidal beaches, central west coast of India. International Journal of Sediment Research, 29(3), 402-413.

[21] Raj, J. K. (1982). Net direction and rates of present-day beach sediment transport by littoral drift along the East Coast of Peninsular Malaysia. Geological Society Malaysia Bulletin, 15, 5770.

[22] Wong, P. P. (1981). Beach changes on a monsoon coast, Peninsular Malaysia. Bulletin of the Geological Society of Malaysia, (14), 5974.

[23] Ariffin, E. H., Sedrati, M., Akhir, M. F., Yaacob, R., \& Husain, M.
L. (2016). Open Sandy Beach Morphology and Morphodynamic as Response to Seasonal Monsoon in Kuala Terengganu, Malaysia. Journal of Coastal Research, 75(1), 1032-1036.

[24] Husain, M. L., \& Yaakob, R. (1995). Beach Erosion Variabiltiy during a Northeast Monsoon: The Kuala Setiu. Science and Technology, 3(2), 337-348.

[25] Koiting, R., Saleh, E., Madin, J., Aung, T., \& Mustajap, F. (2015). Morphologies changes during pre- and post- soutwest season in Mantanani Besar Island, Kota Belud, Sabah. Borneo Scinece, 36(1), 33-43. 